\title{
THE IMPACT OF VARIATIONS IN TEMPERATURE AND RELATIVE HUMIDITY OF SOIL ON GEOGRAPHICAL DISTRIBUTION OF SUBTERRANEAN TERMITES AT SOME EGYPTIAN GOVERNORATES
}

\author{
EL-BASSIOUNY, A. R. ${ }^{1}$, S. M. ABOL-MAATY ${ }^{2}$, \\ R. M. ABDEL-MOATY ${ }^{1}$ and S. M. HASHIM ${ }^{1}$ \\ 1- Plant Protection Res., Inst. ARC, Dokki, Giza., Egypt \\ 2- Central Lab. of Agricultural Climate, ARC, Dokki, Giza., Egypt
}

(Manuscript received 24 October 2011)

\begin{abstract}
Data showed that, the subterranean termite Psammotermes hypostoma (Desn.), recorded in most variable temperatures degrees ranged from 21.9-32.1 $\mathrm{C}^{\circ}$ of Egyptian Governorates, while the subterranean termite, Anacanthotermes ochraceus (Borm.), was found in most areas with temperature degrees ranged from 21.9-31.3C . But the subterranean termite Amitermes desertorum (Desn.), was the least spread, and found only in high temperature degrees 28.2 and 31.3. According to obtained data the $P$. hypostoma, was more existent at most temperature degrees, followed by $A$. ochraceus, which distributed in lower temperatures of soil, but the subterranean termite $A$. desertorum, was very limited and confined with high soil temperature degrees. On the other hand obtained data clarified that, the subterranean termite $P$. hypostoma found in most variable relative humidity degrees of soil ranged from 27.5-80.5Rh, while the subterranean termite, $A$. ochraceus was found in some areas with variable Rh degrees of soil ranged from 49.5-66.9. Also the subterranean termite $A$. desertorum was found with Rh degrees of soil ranged from 4149.5. According to obtained data the $P$. hypostoma, was more existent at most Rh degrees, followed by $A$. ochraceus, but the subterranean termite $A$. desertorum, was very limited and confined with low range of $\mathrm{Rh}$ degrees of soil. As a general trend there is relationship between termite distribution and the tested factors and the subterranean termite can be life in long rang of temperatures and relative humidity.
\end{abstract}

\section{INTRODUCTION}

Three species of subterranean termites defined and distributed in most of Egyptian desert. Termites are social insects life in tunnels and can be able to adapt in a wide range of environments (temperatures and relative humidity). Also subterranean termites can be able to life in the most of soil types (sand silt, sandy clay, sandy loam and loamy clay), and are found in the arid and semi-arid region (ElBassiouny et. al. 2009). In Egypt, subterranean termites P. hypostoma 
(Rhinotermitidae), A. ochraceus (Hodotermitidae) and $A$. desertorum (Termitidae) are distributed in most of Lower, Middle and Upper Egypt. Subterranean termites cause a dangerous damage for buildings and crops all over the world. El-Bassiouny (2001), mentioned that, the termite activities were affected by soil conditions in which subterranean termite live. Effects of environmental factors on the subterranean termite were studied by many authors e.g., Said (1979); Abou-Ghadir \& Khalifa (1982); Khalifa (1982); Morsy et. al. (1982); Abdel-Wahab et. al. (1983); Rizk et. al. (1985) and Salman et. al . (1987).

Present work was conducted to study the effect of soil temperatures and relative humidity degrees on subterranean termite distribution at some Egyptian Governorates.

\section{MATERIALS AND METHODS}

\section{Chosen test areas:}

The tested areas were chosen in some governorates of lower, middle and upper Egypt which has subterranean termite and a variable weather condition (temperature and relative humidity). In Cairo, one area; El-Nozha district, Heliopolis, Qalubia, one area; Abu Zaabal, Alexandria, one area; Justice habitations, Smouha district, Al-Behera, one area; Nubaria, Ismailia, two areas; Agric., Res., Station at Ezz El-Deen district and El-Kassasen city, Sharqia, one area; Sangha village, Kafr Sakr, South Sinai, one area; Wadi-Feran, Sant catereen, North Sinai, one area; El-Shaikh Zouied city, Fayoum, two areas; Al-Masatly village, Kom-Oshim, Tamia and Al-Saidia village, Sennoures, Bani-Suef, one area; Sedmant El-Gabal monastery, Ehnasia almadina, Al-Minya, one area; Absuan manor, Samallout, Assuit, one area; Experiment Station, Assuit University, Sohag, one area; El-Kawla Village, Akhmeem district, Asswan, one area; Abu El-Rish kibli, M. Matrouh, one area; Abu Bakr El-Seddeek district, Siwa oasis and New valley, one area; mut village.

\section{Data obtained source:}

Data of temperatures and relative humidity were obtained from Central Lab., of Agricultural Climate, Agric., Res., Center, Dokki, Giza., Egypt. Data were calculated as mean of 10 months throughout 10 years from year 2000-2010.

\section{Termite collections:}

Termites were collected from areas known to the injury of published research by two methods; first; El-Sebay modified traps (El-Sebay 1991) were used in survey and collecting of subterranean termite individuals in open infested areas at the tested Governorates. (Fig. 1), showed used trap for catch of termites. The traps were soaked 
in water and buried in the ground at $15 \mathrm{~cm}$ depth. 25 traps were distributed throughout infested area and aligned in 5 rows $\times 5$ columns under the ground level with $2 \mathrm{~m}$ intervals between the traps (Fig. 2). Traps were collected after two weeks for each tested area and sent to the termite laboratory at Plant Protection Research Institute, Dokki, Giza for separating of individuals; El-Sebay (1993); El-Bassiouny (2001); Abdel-Latif N. A. (2003) and Ahmed (2003), in Egypt, used the same traps method in termite collection. Second; in infested buildings, termites were collected from infested wood pieces by small brush in plastic box contained moistened carton pieces and sent to the termite laboratory for work completion. Samples were labeled and classified to its species in Wood boring Division and checked in Taxonomy Department, Plant Protection Research Institute, Dokki, Giza, Egypt

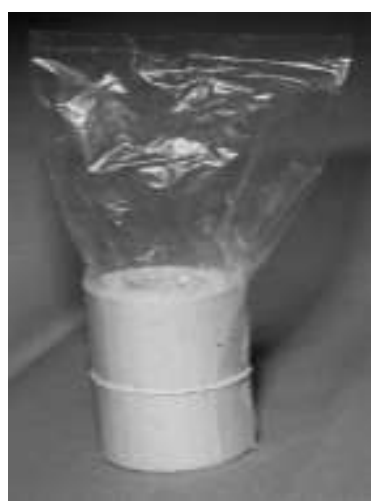

Fig. (1): El-Sebay

modified trap

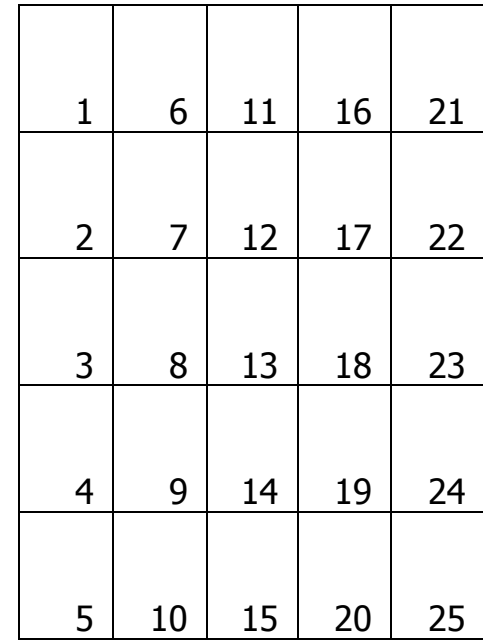

Fig. (2): Traps distribution in infested area.

\section{RESULTS AND DISCUSSION}

\section{Effect of soil temperature on termite distribution:}

Table (1), clarified that, the subterranean termite $P$. hypostoma was the most distributed species; it was recorded in 13 areas of 13 Governorates of variable temperature degrees ranged between $21.9-32.1 \mathrm{C}^{\circ}$. The subterranean termite $A$. ochraceus was in the second rank, whereas it found in 6 areas in 6 governorates at variable temperatures degrees ranged between $21.9-31.3 C^{\circ}$. While the species $A$. desertorum, was rare in the tested areas and found only in two governorates at temperature degrees ranged between 28.2 and 31.3. 
Generally, the subterranean termite $P$. hypostoma, prefer wide range of soil temperatures, followed by subterranean termite $A$. ochraceus, while the termite $A$. desertorum, was found rarely, commonly in areas at low range of soil temperatures, so, we can say that, the three species of Egyptian subterranean termite is openly related to the soil weather.

Morsy et. al. (1982), resulted that temperature is one of the determining factors in survival and food consumption. The living period of the tested workers of $P$. hypostoma, was very low when they were maintained under the low or high constant temperature. The most favorable temperature for surviving was around $30^{\circ} \mathrm{C}$, whereas it was around $25^{\circ} \mathrm{C}$ for food consumption.

Abdel-Wahab et. al. (1983), in Egypt, reported that, the relation between termite activity and temperature and relative humidity revealed that $60 \%$ of the Psammotermes hypostoma (Desn.) activity were attributed to the meteorological variables, the minimum relative humidity seems to be the most effective variable followed by the maximum temperature.

Salman et. al. (1987), in Egypt, stated that, the climatic variation (minimum and maximum air temperature) at $5 \mathrm{~cm}$ above the soil surface accounted for $73 \%$ of the termite activity of $P$. hypostoma, with minimum air temperature having the greatest effect.

Shahid and Akhtar (1992), found that, the largest population of Odontotermes feae was abundant in May $\left(30^{\circ} \mathrm{C}\right.$ and $\left.64 \% \mathrm{RH}\right)$.

El-Bassiouny et. al. (2009), mentioned that, the subterranean termite $P$. hypostoma, was distributed in all types of soil (sandy silt, sandy clay and rarely in loamy clay soil types), followed by the $A$. ochraceus which occupied most of the governorates in lower Egypt and distributed specially in sandy loam soil and rarely in sandy clay and loamy sand soil types, while the termite $A$. desertorum was only find in Asswan and New Valley Gov., and frequent in locations where all types of vegetation present mainly palm plantations, shrubs and ornamental trees which are cultivated in soils rich of organic matter with high moisture content. 
Table 1. the mean of soil temperatures and recorded termites at some Egyptian governorates throughout years 2000 to 2010 compared with termite distribution

\begin{tabular}{|c|c|c|c|c|c|c|c|c|c|c|c|c|c|c|}
\hline \multirow{2}{*}{ Gov } & \multicolumn{12}{|c|}{ The mean of soil temperatures / months throughout years 2000 to 2010} & \multirow{2}{*}{ Mean } & \multirow{2}{*}{$\begin{array}{l}\text { Termite } \\
\text { species }\end{array}$} \\
\hline & Jan. & Fib. & Mar. & Apr. & May & Jun & Jul & Aug. & Sept. & Oct. & Nov. & Dec. & & \\
\hline 1- Cairo & 17.7 & 17.0 & 19.1 & 23.2 & 27.4 & 30.4 & 33.5 & 34.0 & 33.2 & 27.3 & 26.1 & 19.7 & 25.7 & P. hypostoma \\
\hline 2-Qalubia & 16.5 & 16.5 & 17.1 & 20.3 & 23.7 & 27.4 & 30.9 & 32.2 & 32.2 & 25.6 & 27.1 & 19.3 & 24.1 & P. hypostoma \\
\hline 3- Alexandria & 15.0 & 14.5 & 15.9 & 21.6 & 27.0 & 31.1 & 33.8 & 33.5 & 31.5 & 27.5 & 21.9 & 15.4 & 24.1 & P. hypostoma \\
\hline 4- Al-Behera & 20.9 & 17.8 & 18.3 & 19.1 & 28.6 & 25.5 & 30.8 & 31.1 & 29.7 & 21.9 & 18.6 & 17.8 & 23.4 & A. ochraceus \\
\hline 5- Ismailia & 14.1 & 14.2 & 15.2 & 20.9 & 25.2 & 28.2 & 28.5 & 28.9 & 28.2 & 24.7 & 19.9 & 14.5 & 21.9 & $\begin{array}{l}\text { P. hypostoma } \\
\text { A. ochraceus }\end{array}$ \\
\hline 6- Sharqia & 17.6 & 16.5 & 17.6 & 23.0 & 27.7 & 29.8 & 32.0 & 32.5 & 31.4 & 24.7 & 25.9 & 21.1 & 25 & A. ochraceus \\
\hline 7- South Sinai & 14.4 & 14.6 & 16.1 & 22.0 & 26.5 & 29.6 & 30.6 & 31.0 & 29.7 & 25.9 & 21.0 & 15.0 & 23.1 & P. hypostoma \\
\hline 8- North Sinai & 14.6 & 15.0 & 17.0 & 23.2 & 27.9 & 31.1 & 32.8 & 33.0 & 31.2 & 27.1 & 22.2 & 15.5 & 24.3 & P. hypostoma \\
\hline 9- Fayoum: & 18.9 & 17.5 & 21.2 & 26.2 & 31.2 & 33.4 & 36.0 & 35.7 & 34.1 & 29.1 & 25.1 & 20.2 & 27.4 & $\begin{array}{l}\text { P. hypostoma } \\
\text { A. ochraceus }\end{array}$ \\
\hline 10- Bani-Suef & 16.9 & 17.3 & 19.2 & 24.0 & 26.7 & 28.9 & 32.1 & 33.7 & 31.5 & 28.2 & 24.0 & 18.8 & 25.2 & P. hypostoma \\
\hline 11- Al-Minya & 13.3 & 14.1 & 16.8 & 21.7 & 23.6 & 28.6 & 33.1 & 34.2 & 31.2 & 28.4 & 24.6 & 19.3 & 24.1 & P. hypostoma \\
\hline 12- Assuit & 23.6 & 24.3 & 27.7 & 33.1 & 38.0 & 39.5 & 40.9 & 40.7 & 39.4 & 35.7 & 24.9 & 24.1 & 32.7 & P. hypostoma \\
\hline 13- Sohag & 20.6 & 22.3 & 24.7 & 30.4 & 36.3 & 35.9 & 38.1 & 37.9 & 39.4 & 32.7 & 24.8 & 21.9 & 30.4 & P. hypostoma \\
\hline 14- Asswan: & 17.7 & 20.3 & 21.7 & 27.6 & 34.5 & 32.3 & 35.2 & 35.1 & 39.4 & 29.6 & 24.7 & 19.7 & 28.2 & \begin{tabular}{|l|} 
P. hypostoma \\
A. desertorum
\end{tabular} \\
\hline 15- M. Matrouh & 18.0 & 16.1 & 17.1 & 20.4 & 27.8 & 28.3 & 32.3 & 32.3 & 30.6 & 24.7 & 20.2 & 16.6 & 23.7 & A. ochraceus \\
\hline 16- New valley & 20.6 & 21.1 & 24.8 & 32.8 & 37.2 & 38.8 & 39.7 & 39.6 & 37.2 & 33.7 & 27.8 & 22.1 & 31.3 & $\begin{array}{l}\text { P. hypostoma } \\
\text { A. ochraceus } \\
\text { A. desertorum }\end{array}$ \\
\hline
\end{tabular}




\section{Effect of soil relative humidity on termite distribution:}

Data in Table (2), showed that, the subterranean termite $P$. hypostoma was the most distributed species; it was recorded in 13 areas of 13 Governorates of variable relative humidity ranged between 27.5-80.5 $\mathrm{RH}$., while the species of subterranean termite $A$. ochraceus was follow and it found 6 areas in 6 governorates at variable relative humidity degrees ranged between $49.5-66.9 \mathrm{RH}$., but the species of $A$. desertorum, was rare and found in 2 areas in 2 governorates at relative humidity degrees ranged between 41.0 and $49.5 \mathrm{RH}$.

In general, subterranean termite $P$. hypostoma, prefer the wide range of relative humidity, followed by subterranean termite $A$. ochraceus, while the termite $A$. desertorum was found at low range of relative humidity, so, we can see, the Egyptian subterranean termite is openly related to the soil weather.

Data in tables (1\&2), showed that, there is a relationship between temperatures and relative humidity with termite distribution in different areas at some Egyptian governorates.

Abou-Ghadir and Khalifa (1982), in Egypt, studied the foraging activity of desert subterranean termite, Psammotermes hypostoma (Desn.) in relation to the recycling of the superficial wood available in the desert ecosystem, as well as the soil environmental factors, the results indicated that the termite infestation is confined to rich in moisture content at deep layers near the soil surface, beside to the availability of the superficial wood and surface weed vegetation.

Khalifa (1982), in Egypt, determined the moisture of soil layers is the limiting factor for Psammotermes hypostoma (Desn.), food consumption and survival under constant and variable temperature and the results revealed that the living period of the tested workers was very low when they were under the low or high constant temperature.

Rizk et. al. (1985), in Egypt, showed that, soil moisture had affected the flight of Psammotermes hypostoma (Desn.). 
Table 2. the mean of relative humidity of soil and recorded termites at some Egyptian governorates throughout years 2000 to 2010 compared with termite distribution

\begin{tabular}{|c|c|c|c|c|c|c|c|c|c|c|c|c|c|c|}
\hline \multirow[t]{2}{*}{ Gov. } & \multicolumn{12}{|c|}{ The mean of relative humidity / months throughout years 2000 to 2010} & \multirow[t]{2}{*}{ Total } & \multirow{2}{*}{$\begin{array}{l}\text { Termite } \\
\text { species }\end{array}$} \\
\hline & Jan. & Fib. & Mar. & Apr. & May & Jun & Jul & Aug. & Sept. & Oct. & Nov. & Dec. & & \\
\hline 1- Cairo & 57.4 & 57.9 & 60.9 & 55.5 & 36.1 & 50.3 & 56.8 & 57.4 & 56.8 & 58.8 & 58.1 & 59.8 & 55.8 & P. hypostoma \\
\hline 2-Qalubia & 62.5 & 57.0 & 53.0 & 53.5 & 54.0 & 50.5 & 59.5 & 62.0 & 51.0 & 52.0 & 54.0 & 63.0 & 56.0 & P. hypostoma \\
\hline 3- Alexandria & 81.5 & 77.5 & 76.0 & 77.0 & 78.0 & 81.5 & 82.0 & 76.5 & 79.0 & 79.0 & 81.0 & 82.0 & 79.5 & P. hypostoma \\
\hline 4- Al-Behera & 67.0 & 64.0 & 61.0 & 61.5 & 59.0 & 62.0 & 66.0 & 67.5 & 65.0 & 63.0 & 65.0 & 68.0 & 64.0 & A. ochraceus \\
\hline 5- Ismailia & 59.0 & 56.0 & 54.5 & 53.5 & 52.5 & 54.5 & 55.5 & 56.0 & 56.0 & 55.5 & 58.5 & 66.5 & 56.5 & $\begin{array}{l}\text { P. hypostoma } \\
\text { A. ochraceus }\end{array}$ \\
\hline 6- Sharqia & 62.5 & 66.5 & 59.5 & 57.0 & 54.5 & 59.5 & 65.5 & 67.0 & 62.5 & 62.0 & 62.0 & 65.0 & 62.0 & A. ochraceus \\
\hline 7- South Sinai & 68.2 & 66.5 & 68.0 & 64.2 & 40.2 & 68.5 & 69.6 & 70.8 & 70.2 & 71.3 & 69.8 & 69.8 & 66.4 & P. hypostoma \\
\hline 8- North Sinai & 79.0 & 79.5 & 76.5 & 78.0 & 81.5 & 83.5 & 83.5 & 80.0 & 82.5 & 80.0 & 78.5 & 81.5 & 80.5 & P. hypostoma \\
\hline 9- Fayoum: & 56.5 & 54.5 & 55.0 & 50.5 & 48.5 & 50.5 & 52.0 & 52.5 & 52.0 & 54.0 & 54.0 & 59.0 & 53.5 & $\begin{array}{l}\text { P. hypostoma } \\
\text { A. ochraceus }\end{array}$ \\
\hline 10- Bani-Suef & 54.0 & 50.5 & 48.5 & 49.0 & 49.5 & 45.0 & 49.0 & 49.5 & 45.0 & 49.0 & 53.5 & 56.0 & 50.0 & P. hypostoma \\
\hline 11- Al-Minya & 36.5 & 32.5 & 26.5 & 22.0 & 18.5 & 22.0 & 24.5 & 24.0 & 21.0 & 27.5 & 34.5 & 39.0 & 27.5 & P. hypostoma \\
\hline 12- Assuit & 53.5 & 50.5 & 47.5 & 43.0 & 38.0 & 41.5 & 45.0 & 47.0 & 44.5 & 43.0 & 47.5 & 48.5 & 45.5 & P. hypostoma \\
\hline 13- Sohag & 50.9 & 47.3 & 43.3 & 36.2 & 28.0 & 38.5 & 40.8 & 42.1 & 43.4 & 47.8 & 50.8 & 49.5 & 43.3 & P. hypostoma \\
\hline 14- Asswan: & 45.5 & 39.2 & 34.0 & 28.0 & 26.7 & 29.0 & 34.5 & 36.2 & 37.5 & 45.0 & 45.5 & 43.5 & 41.0 & $\begin{array}{l}\text { P. hypostoma } \\
\text { A. desertorum }\end{array}$ \\
\hline 15- M. Matrouh & 68.5 & 69.3 & 67.8 & 65.8 & 41.0 & 68.8 & 70.8 & 72.0 & 69.3 & 63.8 & 74.8 & 72.3 & 66.9 & A. ochraceus \\
\hline 16- New valley & 60.0 & 53.5 & 46.0 & 41.5 & 39.5 & 43.0 & 41.0 & 43.5 & 48.0 & 54.5 & 65.5 & 60.2 & 49.5 & $\begin{array}{l}\text { P. hypostoma } \\
\text { A. ochraceus } \\
\text { A. desertorum }\end{array}$ \\
\hline
\end{tabular}




\section{REFERENCES}

1. Abdel-Latif N. A. 2003. Ecological and control studies on certain subterranean termite species. Ph.D. Thesis, Fac. Agric. Cairo University.

2. Abdel-Wahab A. M., M. R. Rizk, M. H. Hussin, T. K. Abd El-Raof and M. S. ElTaib. 1983. Surface activity of sand termites Psammotermes hypostoma Desneux in Aswan. Assuit J. Agric. Sec., 14(3): 99-108.

3. Abou-Ghadir M. F. and M. E. Khalifa. 1982. Desert termite and foraging populations and their relation to superficial wood and soil. Assuit J. Agric. Sci., 13 (3): 79-86.

4. Ahmed H. M. 2003. Ecological and control studies on Cairo subterranean termites under Fayoum conditions Ph.D. Thesis, Fac. Agric. Cairo University, Fayoum branch.

5. El-Bassiouny A. R. 2001. A study on the ecology and biological control of subterranean termites M. Sc. Thesis, Fac. Agric. Al-Azhar University.

6. El-Bassiouny A. R, M. K. Abbas, N. N. Abdel-Malak and A. A. Mosa. 2009. Study on the effect of soil type on subterranean termite distribution with special reference to the soil properties occurred to termite activity Egyptian J. of applied Sci., Vol. 24 No. (10B) 661-670

7. El-Sebay Y. 1991. A modified trap for El-Sebay subterranean termites. Fourth Arab Cong. of Plant Protection.

8. El-Sebay Y. 1993. Ecological studies on the harvester termites $A$. ochraceus (Burm.) in Egypt. Assuit J. Agric. Sci., 24 (4): 35-47.

9. Khalifa E. M. 1982. Desert termite activities in relation with soil activities and characteristics Assuit J. Agric. Sci., 13 (3): 55-71.

10. Morsy M. M., M. M. Rizk and F. M. Khalil. 1982. Effect of Thermo Rhythm on termite food consumption. Assiut J. Agric. Sci., 13 (3): 43-50.

11. Rizk M. M. A., A. K. El-Sayed, A. Maher Ali and S. A. Eraky. 1985. Flight activity and annual cost fluctuation and sand termite Psammotermes hypostoma Desenex, western Desert, Egypt. Assiut J. Agric. Sci., 16 (2): 137148.

12. Said W. A. 1979. Ecological and toxicological studies on Fam. Hodotermitidae. M. Sc. Thesis, Fac. Of Agric., Ain-Shams Univ., Egypt.

13. Salman A. G. A., M. A. A. Morsy and A. A. Sayed. 1987. Foraging activity of the sand termite, Psammotermes hypostoma Desn. In the New Valley, Egypt. Assuit J. Agric. Sci., 18 (4): 51-57.

14. Shahid, A. S. and M. S. Akhtar. 1992. Termite (Isoptera) population and damage in sugarcane field at Gojra, Tobatek, Singh, Pakistan. Pakistan J. of Zoology, (2): 161-164. 


\section{تأثير إختلافات درجات الحرارة والرطوية النسبية للتربة على التوزيع الجغرافى للنمل الأبيض تحت أرضى فى بعض محافظات مصر}

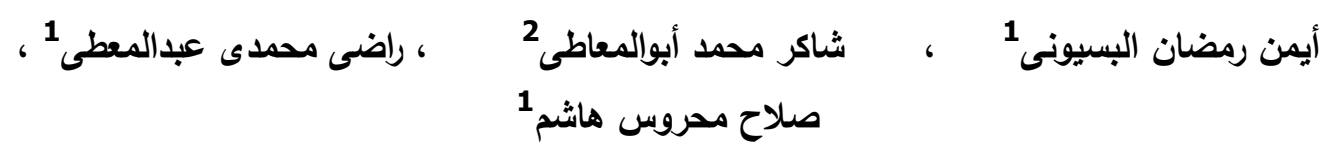

$$
\begin{aligned}
& \text { 1- مركز البحوث الزراعية - معرة بحوث وقاية النباتات - الدقى - جيزه - مصر }
\end{aligned}
$$

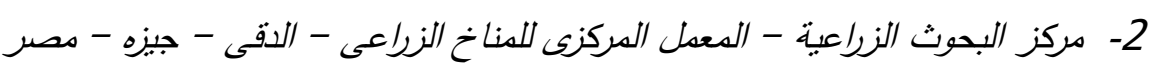

أثتتت الننائج المنحصل عليها أن نوع النمل الأبيض تحت أرضى " ساموترمس هيبوستوما " هو

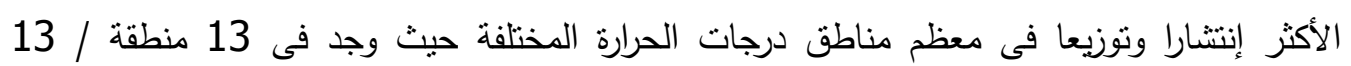

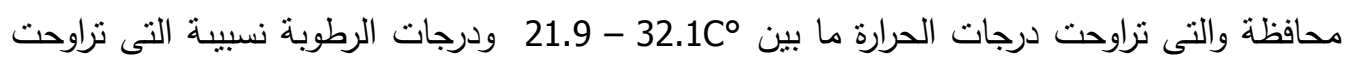

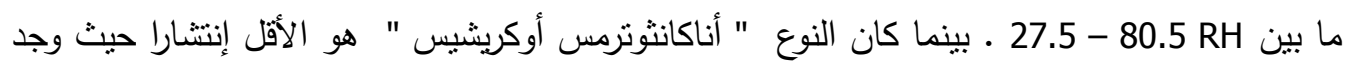

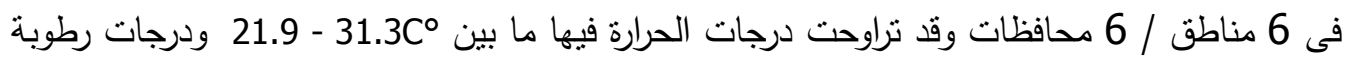

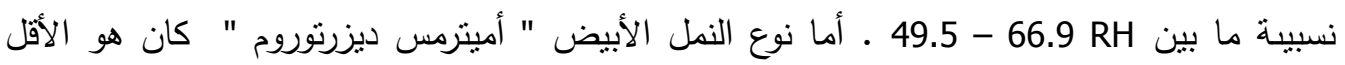

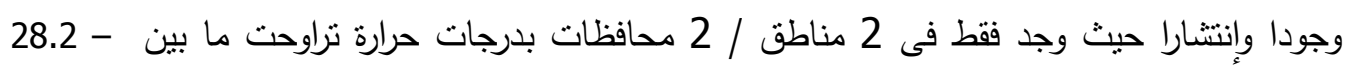

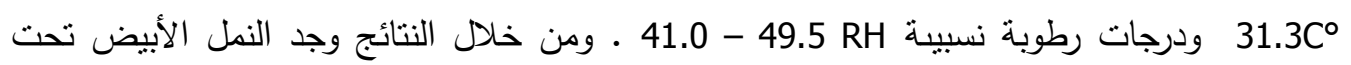

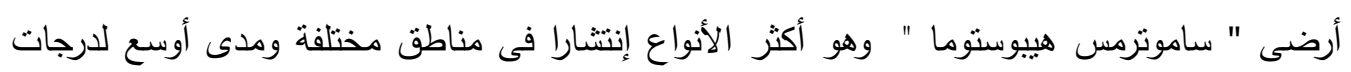

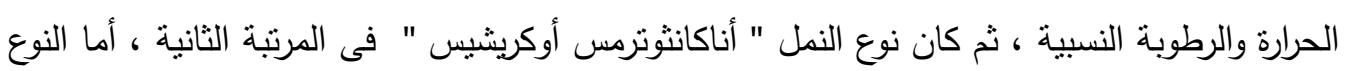

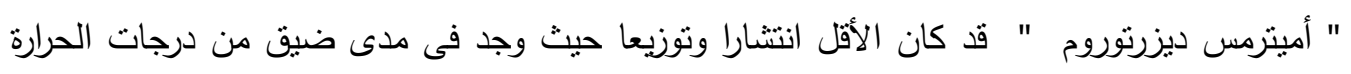

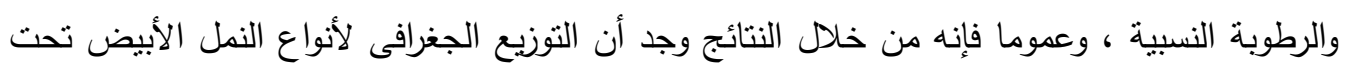

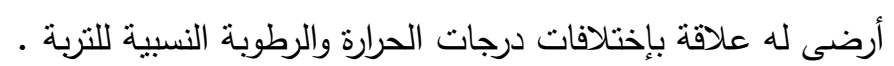

